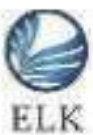

Asia Pacific Journals

www.elkjournals.com

\title{
THE ROLES OF DJIBOUTI PORT IN STRENGTHENING THE ETHIO-DJIBOUTI ECONOMIC RELATIONS
}

\author{
Mulubrhan Atsbaha \\ Department of Civics and Ethical Studies, \\ College of Social Science and Humanities, \\ Adigrat University, Adigrat, Ethiopia, \\ Email: mule17ma@gmail.com
}

\begin{abstract}
The main purpose of this study was to assess the roles of Djibouti port in strengthening the EthioDjibouti economic relations. The study applied descriptive type of methodology and qualitative approach. The study used primary and secondary data collection methods. Primary data was elicited through semi-structured interview with key informants whereas secondary data was gathered from relevant literatures, such as books, theses, journal articles, published and unpublished materials, treaties, government documents, and etc. The primary and secondary data used in this study were analyzed through thematic analysis method. Therefore, the study found that the main factors that led Ethiopia to use Djibouti port have been not only its geographical proximity and infrastructural connection of the two countries via road and railway, but also the pacific Ethio-Djibouti relations, Ethiopia's landlockedness as a result of Eritrea's independence, and Ethio-Eritrea conflict 1998-2000. The study revealed that Djibouti port plays vital economic roles to Ethiopia serving as the main seaport to its foreign trade, and Djibouti generates revenue from Ethiopia's use of its port and enhanced its economic development. The heavy dependency of Ethiopia on Djibouti port, foreign powers influence, political instability in the Horn of Africa, managerial snags, infrastructural and Djibouti port operational problems hinder Djibouti port in strengthening the economic relations. Given the infrastructural links, growing Ethiopian economy, and their economic integration, the prospect of continuity of Djibouti port in strengthening the Ethio-Djibouti economic relation most likely seems promising. However, the availability of other ports in terms of less cost and better services will pose a challenge against the Djibouti port and the Ethio-Djibouti economic relations.
\end{abstract}

Key Words: Ethiopia, Djibouti, Djibouti port, Economic relations 


\section{ELK ASIA PACIFIC JOURNAL OF SOCIAL SCIENCE}

ISSN 2394-9392 (Online); DOI: 10.16962/EAPJSS/issn. 2394-9392/2015; Volume 5 Issue 1 (2018)

\section{INTRODUCTION}

Ethiopia has long history of relation with the outside world. This goes back to the first century $\mathrm{AD}$ when there is evidence of relation with ancient Greek, Egypt, the Arabia world kingdoms, India and extra

(Ethiopian Economics Association/ Ethiopian Economic Policy Research Institute, 2009:3). Ethiopia maintained its independence to the modern era, except during the five years (1936-41) of the Italian occupation. This brought it as decolonization actor for the cause of Africa and enhanced its position in African politics, which is evident in the foundation of such as Economic Commission for Africa and OAU (now AU) in Addis Ababa in 1963. As a result, almost all African states have diplomatic relation with Ethiopia. Except with Somalia during the imperial period and during the Derg regime and recently with Eritrea (19982000), Ethiopian has had good relation with its neighbors and the Horn of African countries (Tewodros and Halellujah, 2014:89).

Djibouti is one of the African countries to which Ethiopia is tied most for economic relation. In fact, such relation is traced back to the beginning of colonial period of France to Djibouti. However, formal Ethio-Djibouti relation started in 1984 following the latter's independence from France in 1977 (Styan, 2013:3-5). Needing its port for external gateway, successive Ethiopian regimes strived to maintain good relations with Djibouti. Both the emperor Minilik and Haile Selassie regimes showed a strong commitment in their respective foreign policies towards Djibouti and provided due attention of getting Ethiopia to access the sea to the extent of claiming Djibouti was part of Ethiopia. This was mainly for economic concern relating to the Djibouti port and connected via railway (Endalcachew and Kidanu, 2015:9-10). With the coming to power of Derg in 1974, however, Ethiopia gave up claim to incorporate Djibouti with Ethiopia and showed interest to support its independent existence (Urgassa, 2014:36).

In the post-1991 period, especially Ethiopia's loss of the Eritrean-based ports (Assab and Massawa) following the Ethio-Eritrean conflict of the 1998-2000 has intensified the intensity and dimension of their economic tie (Styan, 2013:3). After this war, the two countries tie is expanded in other areas like transport and communications, trade and investment, peace and security issues, electric power and potable water (Mormul, 2016:264). 


\section{ELK ASIA PACIFIC JOURNAL OF SOCIAL SCIENCE}

ISSN 2394-9392 (Online); DOI: 10.16962/EAPJSS/issn. 2394-9392/2015; Volume 5 Issue 1 (2018)

The Ethio-Djibouti relation has for long been constructive and a good example of mutual partnership between landlocked and transit developing countries (Almaty Program of Action, 2013:9). Ethiopia has no sea of its own that in turn imposes heavy burden while using the Djibouti port. For Djibouti, Ethiopia is a primary economic partner using its port (Anbalagan and Kanagaraj, 2014:2). Many studies have been conducted on the overall Ethio-Djibouti relation. However, none appears to be addressed based on Djibouti port role in strengthening the EthioDjibouti economic relations. This study aimed to fill this gap by exploring the role of Djibouti port in strengthening the EthioDjibouti economic relations.

\section{OBJECTIVES}

The objective of the study was to assess the roles of Djibouti port in promoting the EthioDjibouti economic relations. Particularly, the study was intended to investigate the factors that led Ethiopia to use the Djibouti port as its seaport outlet, probe in to the economic contributions of Djibouti port to Ethiopia, examine the advantages Djibouti gets from Ethiopia's use of the Djibouti port, and point out the challenges and prospects of the Djibouti port in strengthening the EthioDjibouti economic relations.

\section{METHODS AND DATA ANALYSIS TECHNIQUE}

This study employed descriptive type of methodology and qualitative approach. The study utilized both primary and secondary data sources. Primary data was collected via semi-structured interview from purposively selected key informants based on their experience about the study topic. The key informants were officials in the Ethiopian Ministry of Foreign Affairs, Ministry of Trade, Ethiopian Shipping and Logistics Services Enterprise (ESLSE), and Importers and Exporters of Ethiopia. Secondary data was gathered from relevant literatures such as books, internet sources, thesis, journal articles, published and unpublished materials, treaties, government documents, and etc.

The study is qualitative in terms of development. It covered a variety of thematic areas that among others include issues within and outside Djibouti port, Ethio-Djibouti economic, political and social relation, conflict sources and collaboration, and etc. To this end, the data collected from the different interview informants (primary sources) and the various secondary materials were arranged thematically first in accordance with their own respective category and blended subsequently and 


\section{ELK ASIA PACIFIC JOURNAL OF SOCIAL SCIENCE}

ISSN 2394-9392 (Online); DOI: 10.16962/EAPJSS/issn. 2394-9392/2015; Volume 5 Issue 1 (2018)

analyzed using thematic analysis method to give meaning for the study.

\section{RESULTS AND DISCUSSION}

\subsection{The Main Factors that Led Ethiopia to} Use Djibouti Port as its Seaport Outlet

\subsubsection{Geographical Proximity and Infrastructure for Ethiopia's Use of Djibouti Port}

Interviewed experts of the Ministry of Foreign Affairs revealed that Djibouti port has become the closest port to Addis Ababa next to Assab, located at $910 \mathrm{kms}$ by road and $781 \mathrm{kms}$ by railway. This geographic nearness makes it the most economical for Ethiopia when compared with other neighboring country ports (Kenya, Somalia, and Sudan). (Ref table 4.1). This has enabled the two countries for better infrastructure interconnection of road and railway transportation in the past, which is widening now in port facilities. Girma (2009:5) asserted that Ethiopia which has become landlocked as a result of colonial loss of Eritrea to Italy, reached an agreement for railway construction that could connect the country with French Somaliland. The railway construction between Addis Ababa and Djibouti started in 1897 was completed in 1917. Followed with this was Djibouti port that became operational for Ethiopia in 1926. Beside, Warsame (2017:6) noted that the newly inaugurated 753-km, Addis AbabaDjibouti railway links Ethiopia with the Djibouti port allows for an average speed of $120 \mathrm{~km} /$ hour, and has a capacity to transport 3500 tonnes per trip, seven times greater than the old railway. Urgassa (2014:42) pointed out that Ethiopia and Djibouti are also connected by road system that goes back to a century.

Furthermore, the pacific relation between Ethiopia and Djibouti, as informants of the Ministry of Foreign Affairs affirmed, had enabled Ethiopia to use the Djibouti port. There have been no major interstate conflicts between the two countries. Mormul (2016:263-264) treated this peaceful relation between the two countries as an exceptional case in the conflict-ridden Horn of Africa. Owed its renaissance mostly to the consequences of the Ethio-Eritrean war (1998-2000), the good Ethio-Djibouti relation has enhanced broader cooperative partnership on regional and global issues of common concern.

Source: Samrawit, 2016

Informants of the Ministry of Foreign Affairs argued that Ethiopia's alternative ports such 


\section{ELK ASIA PACIFIC JOURNAL OF SOCIAL SCIENCE}

ISSN 2394-9392 (Online); DOI: 10.16962/EAPJSS/issn. 2394-9392/2015; Volume 5 Issue 1 (2018)

as; Port Sudan, Berbera and to some extent Mombasa port are at a disadvantageous position due to long distances and they need a work of upgrading if Ethiopia wishes to use them proportional to its interests. Thus, Djibouti port has become a principal port to Ethiopia.

\subsubsection{Eritrea's Independence and Ethiopia's Landlockedness}

Ethiopia had been a maritime country. Its history of access to the sea goes back to the early Axumite era that flourished from the $1^{\text {st }} 7^{\text {th }}$ century $A D$ during which it had conducted international trade via the port of Adulis. Eritrea, which was an integral part of Ethiopia, annexed by the Ottoman Empire in the $16^{\text {th }}$ century and later lost to Italy from 1890-1941 about half a century, and since 1941-1952 was under British control. Consequently, Ethiopia had been landlocked from the early Ottoman Turkish occupation of the area around Red Sea coast up to the federation of Eritrea with Ethiopia in 1952. In the then time the only Ethiopia's outlet to the sea was the Djibouti port (Robera, 2011:49).

According to the informants of the Ministry of Foreign Affairs, Eritrea's federation with Ethiopia in 1952 and transformation into an Ethiopian province in 1962 allowed Ethiopia to had Assab and Massawa ports that lasted from 1952-1991. The Eritrean secessionist movements that started in the early 1960s, however, led it to lose them again since the early 1990s. Consequently, both Assab and Massawa ports were lost to Eritrea when it has become an independent state in 1993. In fact, the landlockedness of Ethiopia as a result of the Eritrea independence has maintained Ethiopia's use of Djibouti port. Although Ethiopia and Eritrea began their relation with good atmosphere, this was only until 1998 when the Ethio-Eritrea conflict broke out. Until 1998, Assab port was the main seaport of Ethiopia handling most of the import-export trade. In relation to this, Styan (2013:53) explained that Eritrea's independence from Ethiopia and with it the consequent latter's loss of sovereignty over the ports of Assab and Massawa had initially limited impact on trade pass through Djibouti port. However, the eruption of the 1998 war between Ethiopia and Eritrea altered this situation.

\subsubsection{The Ethio-Eritrea Conflict 1998- 2000}

Informants from the Ministry of Foreign Affairs argued that the Ethio-Eritrean conflict forced Ethiopia to strengthen its tie with Djibouti port for bilateral economic relations. 


\section{ELK ASIA PACIFIC JOURNAL OF SOCIAL SCIENCE}

ISSN 2394-9392 (Online); DOI: 10.16962/EAPJSS/issn. 2394-9392/2015; Volume 5 Issue 1 (2018)

This conflict has prohibited Ethiopia's access

to the Assab and Massawa of Eritrean ports.

As Berouk (2008:2) noted, it has greatly reinforced the Ethio-Djibouti economic, political and security ties particularly after the two countries signed a trade protocol treaty in 1996. Djibouti and Ethiopia concluded a military cooperation protocol in 1999 that promotes the cooperation of Ethiopia and Djibouti in the area of peace and security. As a result, Ethiopia diverted almost all external trade relation since 1998 towards Djibouti port. It is worth giving to mention that Ethiopia had been using Djibouti port even before the federation of Eritrea with Ethiopia, which enabled it to get access to Assab and Massawa, and even later as the use of them was disrupted due the civil war going on in northern Ethiopia.

\subsection{The Economic Contributions of Djibouti Port to Ethiopia}

Djibouti port serves as Ethiopia's maritime communication-import and export trade. Ethiopia's main imports through Djibouti port include petroleum products, machines, vehicles, spare parts, medical and pharmaceutical products, agricultural and industrial equipment and machines, and consumer commodities. Likewise, Ethiopia exports mainly agricultural products such as coffee, chat, flower, animal products such as meat, finished and unfinished leather items, and other goods (ESLSE, 2017:9).

Djibouti port has been important to Ethiopia's economic integration with the outside world. Even during the 1952-1993 periods when Ethiopia controlled the Eritrean Red sea ports, Djibouti maintained its position as the most important port for its needs. Prior to $1974,60 \%$ of Ethiopia's foreign trade transited via the Djibouti port (Marks, 1974:101). However, this does not mean that there was no problem for Ethiopia in using the Djibouti port. It was hampered from 1970s to the late 1990s due to increasing domestic instability in Djibouti, and Djibouti's connection to regional conflictsYemen, Somalia and Sudan, and the Somali forces interrupted the transit via Djibouti by cutting the railway line during the Ogden war of 1977-78 between Ethiopia and Somalia. Thereafter, Ethiopia switched most of its trade from Djibouti port back to its ports in pre-independence of Eritrea. As a result, in the 1970s until the late 1990s, Ethiopia's external trade on Assab port reached almost $80 \%$, with $20 \%$ passed to the Djibouti port (Chorin, 2010:23). Also, from 1993-1997, when Eritrea and Ethiopia were in cordial relation before going to conflict, Ethiopia's dependency on Assab port reached almost 


\section{ELK ASIA PACIFIC JOURNAL OF SOCIAL SCIENCE}

ISSN 2394-9392 (Online); DOI: 10.16962/EAPJSS/issn. 2394-9392/2015; Volume 5 Issue 1 (2018)

$80 \%$, with $20 \%$ passed to the Djibouti port.

Thus, the economic roles of Djibouti port to Ethiopia and the economic relations has been declined only from the 1970s until the late 1990s and from 1993 to 1997 (Urgassa, 2014:56).

Since 1998, due to Ethio-Eritrean war Ethiopia's diversion of almost all external trade relation towards Djibouti port has hastened the Ethio-Djibouti relations. Djibouti port's handling of Ethiopian trade increased from 1.5 million in $1990(96 \%)$ in to 2.7 in 1995 , to 1.7 in 1997 , to 3.1 in 1998 , to 3.9 in 1999 , to 4.2 in 2002 , to 4.6 in 2007 in to 8.3 million tonnes in 2013 (WBG, 2015:2). As of 2016, Mormul (2016:264) affirmed that the Djibouti port was supposed to give service for almost $90 \%$ of Ethiopian trade.

Informants of the Ministry of Foreign Affairs firmly admitted that Djibouti port has provided services to other sectors of the economy and boost economic development of Ethiopia. In this respect, the Ethiopian Economics Association (2012:2) noted that between 1996/97-2010/11, the service sector and transport services of Ethiopia with respect to Djibouti port grew by $9.4 \%$ and $8.5 \%$ per annum, respectively. Moreover, the FDRE National Planning Commission
(2016:4) added that the real GDP growth averaged $10.1 \%$ per annum during the period of GDPI (2010/11-2014/15). Foreign trade with respect to GDP grew by 2.12 for ten years (1998/99-2008/09). Sea and land transport of imports and exports grew by an average of $12 \%$ and $5 \%$ from 2005 to 2012 respectively. It is safe to infer that growth in seaborne trade was significantly contributed to economic development in which Djibouti port has been playing a critical role on its own part.

The ESLSE $(2017: 2)$ noted that the ESLSE was established in 2011 to render maritime transport services to the Ethiopia's export and import trade, and provides coastal and international marine transport services to and from Djibouti port. The ESLSE is the result of an amalgamation of the former Ethiopian Shipping Lines S.C, Maritime and Transit Services Enterprise, Dry port Services Enterprise, and Comet Transport S.C with more than five decades of dedicated maritime and logistics transport service, has been serving to Ethiopia's international trade since the 1950s. The following Ref table 4.2 shows the total cargoes lifted by the ESLSE based on trade and vessel types.

Source: ESLSE, 2017 


\section{ELK ASIA PACIFIC JOURNAL OF SOCIAL SCIENCE}

ISSN 2394-9392 (Online); DOI: 10.16962/EAPJSS/issn. 2394-9392/2015; Volume 5 Issue 1 (2018)

As it can be seen from table 4.2, the imported cargoes to Ethiopia and cross trade cargoes shipped by ESLSE are slightly in an increasing trend from the year 2008 to 2016. However, the export cargoes transported by the enterprise generally are in fluctuating trend. This large and unanticipated export trade instability is a serious problem for Ethiopia's sustainable development where most of the total import is for investment goods and equipment, fuel, and semi-finished goods. The ESLSE is increasing its cargo import service capacity by adding the number of ships and using charters. The number of ships of the ESLSE today has reached 11. They are making significant contribution in strengthening the nation's maritime transport capacity and increasing the number of cargoes carried by Ethiopian vessels. Now its vessels' total carrying capacity has reached 333,967 tons at a time. Accordingly, even though the performance has decreased to 952,628 tons in 2016 , the cargo transported by ESLSE owned vessels has increased to 1,315,517 tons in 2015 from 763,498 tons in 2008. This entails that ESLSE has played an enhanced role to Ethiopia's import and export trade.

\subsection{The Advantages of Djibouti in Ethiopian Port Service}

Djibouti is primarily a service-based economy mainly dependent on port services. Port services to Ethiopia, and infrastructural cooperation with Ethiopia, and its geostrategic significance for external powers are the principal sources of revenue for Djibouti (Zelalem (2015:26). According to the informant from the Ministry of Trade, Djibouti generates huge amount of revenue from Ethiopia's use of its port and this enables it to intensify economic development. Djibouti's main source of revenue is its port, while Ethiopia has remained at least thus as far as the only being dependent on its port use. As to Styan (2013:8), Djibouti is becoming regional hub in the Horn of Africa because of its port. In the same vein, the International Monetary Fund (2017:6) affirmed that Djibouti's GDP has steadily grown over the past one or two decades, increasing at $6 \%$ average annual rate. Factually, the Ethio-Eritrea war of 1998-2000, and the impact of Ethiopia's economic transformation and growth upon trade that makes Ethiopia dependent on Djibouti port are the contributing factors of Djibouti's economic growth. This has brought a parallel Djibouti's economic development. 


\section{ELK ASIA PACIFIC JOURNAL OF SOCIAL SCIENCE}

ISSN 2394-9392 (Online); DOI: 10.16962/EAPJSS/issn. 2394-9392/2015; Volume 5 Issue 1 (2018)

According to the informants of the Ministry of Foreign Affairs, Ethiopia pays for Djibouti to port services; port rent payment when ships are docking, port maintenance fee or port handling fees, demurrage fee (for import) and storage fee (for export). Annually, Ethiopia paid for port services to Djibouti 2 billion birr in 2006 (Robera, 2011:51), US\$ 700 million in 2009 (UN, 2013:17), and $\$ 850$ million in 2010 (Getachew, 2017:5) for port services. Similarly, an informant of the ESLSE contended that Ethiopia currently pays more than the US $\$ 850$ million per year to Djibouti. Besides, Endalcachew and Kidanu (2015:10) put that the revenue Djibouti generated from Ethiopia accounted for $80 \%$ of Djibouti's economy in 2012. Dagmawi (2016:12) explained that Djibouti port generated direct revenues that estimated from $\$ 65$ million to $\$ 90$ million per year, as of 2016 , most of were generated from Ethiopia.

Data collected revealed that Djibouti port has enhanced mutual economic relations of Ethiopia and Djibouti. As a result of Djibouti port, the two countries' relation has expanded into other spheres of higher level of cooperation and interdependence. This can be understood in the present integration between them through the railway and road infrastructure, trade and investment, electricity, telecommunications, potable water, and peace and security collaboration. Zelalem (2015:24) noted that the complementary economic structure where Ethiopia is landlocked but with a favorable climate for the production of other materials needed by Djibouti that in contrast is characterized by dry weather condition. Hence, Ethiopia rarely has, but Djibouti as a major partner for external sustainable economic relation and for Djibouti Ethiopia to generate port service income as well as its people livelihood, assures the reciprocal nature of their relation. Nevertheless, as informants of the Ministry of Foreign Affairs argued, this does not mean that the landlockedness of Ethiopia does not entail disadvantage. For example, it is exposed to pressures such as giving to Djiboutian citizens' visa-free entry to Ethiopia and free water without counter return from Djibouti, which creates discrepancies in their relation. 
ELK ASIA PACIFIC JOURNAL OF SOCIAL SCIENCE

ISSN 2394-9392 (Online); DOI: 10.16962/EAPJSS/issn. 2394-9392/2015; Volume 5 Issue 1 (2018)

4.4. Challenges and Prospects of Djibouti

Port in Strengthening the EthioDjibouti Economic Relations

\subsubsection{Challenges Facing Djibouti Port in Strengthening the Ethio-Djibouti Economic Relations}

\subsubsection{Heavy Dependency of Ethiopia on Djibouti Port}

Interviewee experts from the Ministry of Foreign Affairs claimed that heavy dependency on Djibouti port has become a bottleneck for Ethiopia's fast-growing economy. Djibouti port is both incapable to handle the fast-growing Ethiopian economic needs, but also accompanies with heavy cost or high tariff rates imposed on Ethiopia by Djibouti port. Besides, Ethiopia is strained and exposed to further influences to provide Djibouti nationals visa-free access to Ethiopia and free water while the reverse is not true which indicates just the burden of Ethiopia's landlockedness. Mormul (2016:277) argued that the benefits of Djibouti as a result of its relation based on Djibouti port has multiplied. In 2014, the Ethiopian government signed an accord to enable Djibouti to extract fresh water free of charge from Shinile Zone in the Ethiopian Somali Region for 30 years. However, the apparent lack of any pay off for Ethiopia can be seen as one of the discrepancies in the mutual relations.

Furthermore, according to the informants of the Ministry of Foreign Affairs, unilateral decisions and actions has affected the EthioDjibouti economic relations, obviously, the upper hand went to the port owner state. As a result, Djibouti keeps rising port price unilaterally because it knows that Ethiopia has no relative alternative or no competitive outlet for market interaction. In this regard, Belete (2014:180) claimed that unilateral influence of Djibouti in tariff and other related issues as a port owner influenced Ethiopia. For instance, in 1998 Ethiopia and Djibouti agreed on minutes that provide 30 days of grace time for containers and issued the payment for stevedoring activities paid to Djibouti port to be per container. However, without prior notice to Ethiopia, Djibouti unilaterally avoided this minute. Consequently, it issued payment for stevedoring activity per hour, reduced the grace time from 30 days to $15-20$ days, and increased its port tariff by 50\% in 2011 . Though Ethiopian was negotiated to reduce this new port tariff at the time where it is issued, Djiboutian refused. Ethiopia had no option but to accept it. Moreover, according to Kindiki (2008:22-23), Ethiopia and 


\section{ELK ASIA PACIFIC JOURNAL OF SOCIAL SCIENCE}

ISSN 2394-9392 (Online); DOI: 10.16962/EAPJSS/issn. 2394-9392/2015; Volume 5 Issue 1 (2018)

Djibouti concluded the Agreement on the Utilization of the Port of Djibouti and Services to Cargo in Transit on $13^{\text {th }}$ April 2002. The agreement proper guarantees Ethiopia unfettered access to the sea and freedom of transit via Djibouti's territory regarding goods originating from and destined to Ethiopia. This agreement also provides any hike of charges and tariffs or change of port regulations by Djibouti must be notified to Ethiopia in advance and presumably discussed accordingly. The implementation of this agreement, however, has been unsatisfactory. Ref Table $\mathbf{4 . 3}$ summarizes Djibouti port charges with respect to the other ports in the region.

Source: Dagmawi, 2016

As it is shown in table 4.3, the charges for stevedoring and port dues for import levied by Djibouti port are too high for both full container of 20'(Twenty Feet Equivalent Unit) and for 40' (Forty Feet Equivalent Unit) or overstated compared to the other ports. Though Ethiopia needs to ease dependency and reduce unnecessary costs at Djibouti port by finding alternative ports, other ports too have their own drawbacks as aforementioned.

\subsubsection{The Influence of Foreign Powers}

The other problem is third-party involvement to disrupt Ethio-Djibouti relation. For example, Egypt is blamed greatly for destabilizing their economic integration. There has been Egypt overt support to the Eritrean Liberation Front stationed in Cairo, military support to Somalia during the 1977-1978 Ogaden War, and military support to Eritrea during the 1998-2000 Ethio-Eritrea War (Berouk, nd:10). In relation to this, Goche (2016:4) maintained that Djibouti has maintained close relations with the US, China, Japan, and others. Economically and politically powerful countries are intensifying their presence in Djibouti not simply due to economic but also for security reasons. Nevertheless, the presence of those powers in Djibouti could erode the independence of Djibouti in pursuing its regional cooperation and integration schemes in the Horn of Africa, particularly with Ethiopia on port use matters.

\subsubsection{Political Instability in the Horn of Africa, and Its Effect on Djibouti Port}

According to Excoffier and Gil (2014:11), inter-state conflicts in the Horn of Africa have long term implications for bilateral 


\section{ELK ASIA PACIFIC JOURNAL OF SOCIAL SCIENCE}

ISSN 2394-9392 (Online); DOI: 10.16962/EAPJSS/issn. 2394-9392/2015; Volume 5 Issue 1 (2018)

relations and regional security. The EthioSomalia (1977-1978) and the Ethio-Eritrean conflict (1998-2000) are notable ones. As noted before, for instance, during the Ethiopia-Somalia war of 1977-1978, the Somali forces cut off the railway line and prevented Djibouti port of giving service to Ethiopia. Similarly, Berouk (2008:2) stated that during the Ethiopia-Eritrea (1998-2000) conflict, Eritrea accused Djibouti of allowing Ethiopia to use its port for importing military arms for the war use. In addition, in 2008, there was a temptation to obstruct Ethiopia from using Djibouti port when Eritrea and Djibouti nearly went to war over their conflictual border called Ras Doumeirah. During this critical time, Ethiopia announced even that it would defend the Ethio-Djibouti trade route. This indicates inter-state conflict impact on Ethio-Djibouti relation and on the port service too.

\subsubsection{Managerial (Institutional) Snags}

According to Cabanius (2003:11-12), multimodal transport of goods and bill of lading has been a source of disagreement between Ethiopia and Djibouti. The bill of lading which Ethiopia requested as a complement to the establishment of an Inland Customs Depot was rejected by Djibouti. Djibouti needs to prevent the Ethiopian
Shipping Lines from using the bill of lading and becoming the only multimodal operator able to operate in the Ethio-Djibouti corridor gaining sole monopoly of the land route in addition to the sea routes. For Djibouti, the bill of lading and multimodal transport can only function and are only acceptable in the context of open competition.

Informant of the Ministry of Trade maintained that corridor institution is vital to governing transit trade operations between landlocked and port owning states over access to and from the sea. However, the Ethio-Djibouti Corridor has not a formal institutional framework and permanent secretary. It is, as a result, run by a committee of experts, and inter-ministerial bilateral committees. As an informant of the ESLSE also noted, the implementation of agreed measures on transit and trade facilitation between those two committees' meetings, however, lacks follow up. In fact, establishing a corridor institution is critical to facilitate transit trade between the two countries. Moreover, the Importers and Exporters informants identified that logistics and bureaucratic challenges, lack of coordination between shippers, forwarders, and port authorities, inadequate containers, congestion, and administration inefficiency become major problems of the Djibouti port 


\section{ELK ASIA PACIFIC JOURNAL OF SOCIAL SCIENCE}

ISSN 2394-9392 (Online); DOI: 10.16962/EAPJSS/issn. 2394-9392/2015; Volume 5 Issue 1 (2018)

as such, Ethiopian importers and exporters are exposed to high costs, and displayed discomfort with Djibouti port services.

\subsubsection{Infrastructural Challenges and} Djibouti Port Operational Problems

According to Elshaday (2016:11), infrastructure interconnection is pivotal in linking landlocked and port owning states. In this regard, Djibouti port is connected with Ethiopia through $910 \mathrm{kms}$ via Galafi. Of this road, only $71 \mathrm{kms}$ is in good condition while the rest is not, which poses a challenge to Djibouti port and the Ethio-Djibouti economic relations.

Djibouti port has also faced operational snags. Transit inefficiency takes a longer time to clear goods through the port in unimodal or multimodal methods. For example, the average unimodal cargo clearance in Djibouti port takes about 10 days that is facilitated in less than 3 days in other ports that have global best practice. The lack of synchronized organization of clearance, and the non-value adding procedures and requirements contributing to the cargo clearance delay from the seaport incur a longer time and unnecessary costs. Transit time in multimodal is relatively short because the number of operators in multimodal is one operator but in unimodal are many requiring much time to complete transit procedures (Dagmawi, 2016:27-29).

As per the Importers and Exporters informants, the other operational hitch that hampers port efficiency is long cargo port dwelling time. Djibouti port grants eight days of grace period and starts charging demurrage cost per container per day after these days. This grace time is short which makes export process accomplishment difficult within this grace time. The longer port dwelling time arises as ships may not come at scheduled time due to schedule cancelation and related factors, timely unavailability of empty containers, and delays of documentation processes. According to Dagmawi (2016: 29), the average dwelling time for a container at Djibouti for both unimodal and multimodal operations is 22 days which is too high compared with Mombasa and Dar-es-salaam which have an average of 7 days grace time. Yet, it is worse from international standards which is a maximum average of 3 days. Generally, the Djibouti port operational inefficiency is resulted from poor infrastructure, inadequate administration and coordination, and congestion. The WBG (2015:5) has rated the performance of the 


\section{ELK ASIA PACIFIC JOURNAL OF SOCIAL SCIENCE}

ISSN 2394-9392 (Online); DOI: 10.16962/EAPJSS/issn. 2394-9392/2015; Volume 5 Issue 1 (2018)

Djibouti port as fair as an international port. However, according to the Islamic Development Bank (2013:1), Djibouti port has been operating at nearly in full capacity (400,000 TEUs), thus, preventing it from taking benefit of its potential.

\subsubsection{Future Prospects and Scenario Analysis in Strengthening Ethio- Djibouti Economic Relations}

It is worthwhile to put three important levels of scenario-most likely, likely, and least likely, to make possible prediction to the role of the Djibouti port in both countries economic relation in the future.

The most likely scenario holds that the prospect of continuity of Djibouti port in strengthening the Ethio-Djibouti economic relations most likely seems promising. The interviewed informant of the Ministry of Foreign Affairs, the Ministry of Trade, and the ESLSE argued that, the current infrastructural links such as the newly inaugurated 753 kms Addis Ababa-Djibouti railway, and a plan to construct new modern railway line, the construction of the new port (port of Doraleh), and the plan to build port of Tadjourah supports this scenario. Moreover, the FDRE National Planning Commission (2016:150) stated that there is a plan to construct a new modern railway line i.e. Mekelle- Tadjourah railway between Mekelle and Tadjoura port. As indicated before, Elshaday (2016:11) described that of the $910 \mathrm{kms}$ road via Galafi except the only $71 \mathrm{kms}$, the remaining portion is not in good condition. As such, Ethiopia and Djibouti have a plan to rehabilitate it. The growing Ethiopian economy and the Ethio-Djibouti economic integrations also could make the relation bright. Ethiopia will remain Djibouti's main partner by virtue of its closest location and the size of its economy and vise-versa.

The likely scenario, as Styan (2013:17) scrutiny examined, shows that the future prospect of Djibouti port in strengthening the Ethio-Djibouti relation likely seems to continue but likely seems to be reduced in the future. Djibouti port will face increased competition from other ports such as Port of Sudan and Berbera as a result of infrastructural development and enhanced capacities. Besides, an informant from the Ministry of Foreign Affairs argued that Ethiopia is in search of alternative ports to reduce its heavy dependency on Djibouti port. As stated in the FDRE National Planning Commission (2016:152), Ethiopia has planned to distribute $60 \%, 30 \%$, and $10 \%$ of its port use between Djibouti, Berbera and 


\section{ELK ASIA PACIFIC JOURNAL OF SOCIAL SCIENCE}

ISSN 2394-9392 (Online); DOI: 10.16962/EAPJSS/issn. 2394-9392/2015; Volume 5 Issue 1 (2018)

Port Sudan respectively. This indicates that Djibouti port likely seems to reduce its importance in the future for the economic relations.

With respect to the least likely scenario, an informant from Ministry of Foreign Affairs argued that, given the availability of other ports in terms of less cost and better services in relation to the highest rate of tariff and its incapability to handle the fast-growing Ethiopian economy, the prospect of Djibouti port giving service to the bilateral relations can be terminated.

It can be inferred that given the infrastructural links such as roads and railway, the growing Ethiopian economy that benefit both countries and the Ethio-Djibouti economic integrations between the two countries, most likely shows the prospects of continuity of Djibouti port in strengthening the Ethio-Djibouti economic relations promising. However, the availability of other ports in terms of less cost and better services will pose a challenge against the Djibouti port and the economic relations of the two countries.

\section{CONCLUSION}

This study was conducted with the aim of assessing the role of Djibouti port for the
Ethio-Djibouti economic relations. It has identified the main motivating factors that led Ethiopia to use Djibouti port has been not only its geographical proximity when compared to other neighboring ports, but also infrastructural links such as the connection of the two countries via road and railway construction that goes back to a century. The landlockedness of Ethiopia as a result of Eritrea's independence from Ethiopia has maintained Ethiopia's use of Djibouti port, and the Ethio-Eritrea conflict of 1998-2000 that denied Ethiopia's access to Eritrean ports much made further to increase Ethiopia's use of Djibouti port.

It has also revealed that Djibouti port plays a vital role for Ethiopia becoming the major outlet of economic integration with the outside world. Despite this, the economic role of Djibouti port to Ethiopia declined from the 1970s until the late 1990s owing to the increasing domestic instability in Djibouti, and the Ethio-Somali war 1977-78, and from 1993 to 1997, when Eritrea and Ethiopia were in cordial relation before going to conflict in the name of border dispute. Since 1998, however, Ethiopia's diversion of almost all trade has towards Djibouti port transformed the Ethio-Djibouti economic relations into a parallel high level of economic interdependence and cooperation. 


\section{ELK ASIA PACIFIC JOURNAL OF SOCIAL SCIENCE}

ISSN 2394-9392 (Online); DOI: 10.16962/EAPJSS/issn. 2394-9392/2015; Volume 5 Issue 1 (2018)

It shows that Djibouti generates revenue from Ethiopia's use of Djibouti port that enables it to enhance its economic development. Djibouti's main source of revenue is its port, while Ethiopia has remained at least as far as the only being dependent on its port use. Djibouti is, in fact, becoming a regional hub in the Horn of Africa as a result of its port. Its GDP has grown steadily over the past one or two decades, increasing at an average annual rate of $6 \%$.

It indicates that the Djibouti port boosts both countries mutual economic benefits. The complementary economic structure reliant is on Ethiopia's landlockedness, but favorable climate for the production of other materials needed by Djibouti, that in contrast is characterized by dry weather condition. Hence, Ethiopia rarely has, but Djibouti as a major partner for external sustainable economic relation and for Djibouti Ethiopia to generate port service income as well as its people livelihood, which makes benefit to be mutual.

However, it does not mean things are straightforward for the Ethiopia-Djibouti economic relation. The heavy dependency of Ethiopia on Djibouti port and the high tariff rates of Djibouti port as a result has become a bottleneck for its fast growing economy.
The influence of foreign powers such as Egyptian attempts to destabilize Ethiopia, and the presence of France, USA and China around and in Djibouti port erode the confidence of Djibouti in pursuing relations with Ethiopia and becomes a challenge for their relations. Instability in the Horn of Africa has long term impact on EthioDjibouti economic relations and its effect on Djibouti port is quite another challenge. For instance, the Ethio-Somalia war of 19771978 and the Ethio-Eritrea war of 1998-2000 were cases in point. Another challenge emanates from management snags like the non-existence of formal institutional framework for the Ethio-Djibouti corridor, and Djibouti's lack of heartfelt willingness on the introduction of Ethiopia's multimodal transport and the bill of lading. More than this, infrastructural problem in the Djibouti port, lack of coordination between stakeholders, shortage of cargo handling and cargo transport equipment within the port, timely unavailability of empty containers, congestion and high costs to importers/exporters are also common. Quite another, poor infrastructure in the road connecting Ethiopia and Djibouti, and Djibouti port operational inefficiencies are the main challenges facing the Djibouti port. 


\section{ELK ASIA PACIFIC JOURNAL OF SOCIAL SCIENCE}

ISSN 2394-9392 (Online); DOI: 10.16962/EAPJSS/issn. 2394-9392/2015; Volume 5 Issue 1 (2018)

Given the infrastructural links such as roads and railway, growing Ethiopian economy, and Ethio-Djibouti economic integrations, the prospects of continuity of Djibouti port in strengthening the Ethio-Djibouti economic relations most likely seems promising. However, the availability of other ports in terms of less cost and better services will pose a challenge against the Djibouti port and the Ethio-Djibouti economic relations.

\section{REFERENCES}

Almaty Program of Action (2013). The Status of Implementation of the Almaty Program of Action (2003-2013).

Democratic Republic of Ethiopia National Report, Ethiopia.

Anbalagan Chinniah and Kanagaraj Kalimuthu (2014). A Study on Problems and Prospects of Transport in Ethiopia: Special Reference with Auto Rickshaw's in Hawassa City, SNNPRS, Ethiopia, IFSMRC AIJRM, Vol. 02.

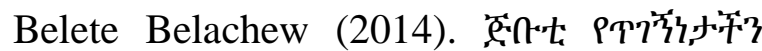
and6.c.? (Djibouti: A Source of Dependency).

Oland Printing Press, Addis Ababa, Ethiopia.

Berouk Mesfin (2008). The Eritrea-Djibouti Border Dispute. Situation Report, Institute for Security Studies.
Berouk Mesfin (nd). The Horn of Africa as a Security Complex: Towards a Theoretical Framework. African Conflict Prevention Program, Institute for Security Studies.

Cabanius, Philippe (2003). Improvement of Transit Systems in the Horn of Africa: Ethiopia's Main Access Corridors to the Sea. UNCTAD working paper, New York.

Chorin Ethan (2010). Articulating a "Dubai Model" of Development: The Case of Djibouti. Published by the Dubai School of Government, Dubai, United Arab Emirates.

Dagmawi Shewangizaw (2016). Assessment of the Impact of Logistic Performance on Trade in Ethiopia. MA Thesis Submitted to School of Graduate Studies of St Mary University, Addis Ababa, Ethiopia.

Elshaday Woldehawariat (2016). Assessment of the Performance of Dry Ports in Ethiopia. MA Thesis Submitted to Addis Ababa Institute of Technology School of Civil and Environmental Engineering Graduate Studies, Addis Ababa University, Ethiopia.

Endalcachew Bayeh and Kidanu Atinafu (2015). Economic Interdependence as a Driving Force for Peace and Security 


\section{ELK ASIA PACIFIC JOURNAL OF SOCIAL SCIENCE}

ISSN 2394-9392 (Online); DOI: 10.16962/EAPJSS/issn. 2394-9392/2015; Volume 5 Issue 1 (2018)

Cooperation: Ethio-Djibouti Relations.

Global Journals Inc.USA, Vol. 15.

ESLSE/Ethiopian Shipping and Logistics

Services Enterprise/(2017). Statistical

Bulletin 2008- 2016.

Ethiopian Economics Association (2012).

Developments in the Transport Sector of Ethiopia. Research Brief, Addis Ababa Institute of Technology, School of Graduate Studies, Addis Ababa University, Addis Ababa, Ethiopia.

Ethiopian Economics Association/Ethiopian Economic Policy Research Institute (2009). A Survey of the Economic and Trade Relationships between China, India, and Ethiopia. Final Report, Addis Ababa, Ethiopia.

Excoffier Marion and Gil Manuel Manrique (2014). East Africa: Competing Dynamics in a Rapidly Changing Region. Regional Briefing Policy, Department DirectorateGeneral for External Policies of European Union.

FDRE National Planning Commission (2016). The FDRE Growth and Transformation Plan II （2015/162019/20). Vol. I. Addis Ababa, Ethiopia. Getachew Begashaw (2017). Port of Assab as a Factor for Economic Development and Regional Conflict. ResearchGet, William Rainey Harper College.
Girma Gelalcha (2009). An Overview of Transport and Trade Facilitation Initiatives and Measures Implemented in Ethiopia. Country paper, Ethiopian Ministry of Trade and Industry.

Goche Stephanie (2016). Djibouti: A Tiny Haven with Strategic Importance in a Troubled Neighborhood. Future Directions International Pty Ltd.

International Monetary Fund (2017). Djibouti: Staff Report for the 2016 Article IV Consultation-Debt Sustainability Analysis. Prepared by the staffs of the International Monetary Fund and the International Development Association.

Islamic Development Bank (2013). New Container Port Raises Djibouti's International logistics Profile. Islamic Development Bank Success Story Series: NO.10.

Kindiki Kithure (2008). Cooperation among the Landlocked and Transit Countries for the Right of Access to and from the Sea of Landlocked Countries, A Consultant's Draft Report, University of Nairobi, Nairobi, Kenya.

Marks Thomas A. (1974). Djibouti: France's Strategic Toehold in Africa. African Affairs, Vol. 73, No. 290.

Mormul Joanna (2016). Ethio-Djiboutian Relations in $21^{\text {st }}$ Century - Towards New African Cooperation. African Studies, 


\section{ELK ASIA PACIFIC JOURNAL OF SOCIAL SCIENCE}

ISSN 2394-9392 (Online); DOI: 10.16962/EAPJSS/issn. 2394-9392/2015; Volume 5 Issue 1 (2018)

Jagiellonian University, Kraków, Poland.

News.

Robera Regassa (2011). Ethio Eritrean

Relations: Problems and Prospects in the

Aftermath of Algiers Peace Agreement. $M A$

Thesis Submitted to Department of Political

Science and International Relations,

School of Graduate Studies, Addis Ababa

University, Ethiopia.

Samrawit Kinfemichael (2016). Assessment

on Logistics Interconnectivity with Special

Reference to Ethiopian Fast Moving

Consumer Goods (FMCG) in Ethiopian

Trading Enterprise. MA Thesis

Submitted to St. Mary's University School of

Graduate Studies Addis Ababa

University, Ethiopia.

Styan David (2013). Djibouti: Changing

Influence in the Horn's Strategic Hub.

Chatham House Africa Programme

AFP BP 01.

Tewodros Makonnen and Halellujah Lulie (2014). Ethiopia, Regional Integration and the COMESA Free Trade Area. Occasional Paper, South African Institute of International Affairs.

United Nations (2013). The Way to the Ocean: Transit Corridors Servicing the Trade of Landlocked Developing Countries. Technical report by the UNCTAD, Series No. 4.
Urgessa Deressa (2014).The Ethio-Djibouti Relations: Implications for Sub Regional Integration Schemes in the Horn of Africa. MA Thesis Submitted to the School of Graduate Studies in International Relations. Addis Ababa University, Ethiopia. Warsame Mohammed (2017). Djibouti Must Improve in Upgrading Infrastructures. Wardheer

World Bank Group (2015). Horn of Africa Initiative Berbera Corridor Program. Background Note.

Zelalem Tesfay Gebreegzabhere (2015). The Political Economy of Geo-Strategic Location and Infrastructure Development in Djibouti: National and Regional Ramifications. In Demessie Fantaye (2015). The Horn of Africa Bulletin Life and Peace Institute, Vol. 26.

\section{Acknowledgment}

All praises to the almighty God who has created this world of knowledge for us. I am deeply thankful to Dr. Belayneh Fikadu for his persistent comment and professional advice all along the article process. Especial thanks deserve to this man of duty and responsibility. The same appreciation also goes to Ato Legesse Hankorie for what he did the same thing. I also would like to extend my 


\section{ELK ASIA PACIFIC JOURNAL OF SOCIAL SCIENCE}

ISSN 2394-9392 (Online); DOI: 10.16962/EAPJSS/issn. 2394-9392/2015; Volume 5 Issue 1 (2018)

gratitude to my families for their enduring

love, perpetual support and encouragements.

I am really honored by you all. It is also worth mentioning that to extend heartfelt acknowledgment to persons and organizations that helped me during conducting the study.

\section{LIST OF TABLES}

Table 4.1. The Distances of Potential Sea Outlet for Ethiopia's in relation to Addis Ababa

\begin{tabular}{|c|c|c|c|c|c|c|c|c|c|}
\hline \multicolumn{10}{|c|}{ Distance of ports in kilometers } \\
\hline $\begin{array}{l}0 \\
0 \\
0 \\
0 \\
0 \\
0\end{array}$ & & 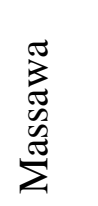 & $\begin{array}{l}\text { 芯 } \\
\text { 令 }\end{array}$ & $\frac{\tilde{J}}{\tilde{D}}$ & 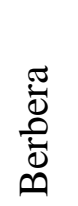 & 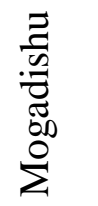 & 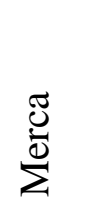 & 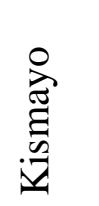 & $\begin{array}{l}\tilde{\Xi} \\
\tilde{D} \\
\tilde{\Xi} \\
\tilde{\Xi} \\
\tilde{\Xi}\end{array}$ \\
\hline Road & Rail & & & & & & & & \\
\hline 910 via Galafi and 847 via & 781 & 1163 & 869 & 1881 & 964 & 1507 & 1567 & 1979 & 2077 \\
\hline Dire Dawa & & & & & & & & & \\
\hline
\end{tabular}

Table 4.2. Total Cargoes Lifted by ESLSE by Trade Type and Vessel Type (in tons)

\begin{tabular}{|ccccccccc}
\hline Year & Import & Export & Cross & Total & Own & Chartered & Own \\
& & & trade & trade & vessel & vessel & share\% \\
2008 & $1,867,692$ & 3,527 & 353,429 & $2,224,648$ & 763,498 & $1,461,150$ & 34 \\
& & & & & & & & \\
2009 & $1,953,492$ & 4,974 & 213,473 & $2,171,939$ & 699,793 & $1,472,146$ & $32 \mathrm{k} 2$ \\
& & & & & & & & \\
2010 & $2,170,353$ & 1,138 & 305,887 & $2,477,378$ & 841,375 & $1,636,003$ & 34 \\
\hline
\end{tabular}


ELK ASIA PACIFIC JOURNAL OF SOCIAL SCIENCE

ISSN 2394-9392 (Online); DOI: 10.16962/EAPJSS/issn. 2394-9392/2015; Volume 5 Issue 1 (2018)

\begin{tabular}{|ccccccccc|}
\hline 2011 & $1,739,571$ & 1,222 & 466,987 & $2,207,780$ & 787,906 & $1,419,874$ & 36 \\
2012 & $3,062,330$ & 492 & 202,062 & $3,264,884$ & 686,404 & $2,578,480$ & 21 \\
& & & & & & & \\
2013 & $3,018,969$ & 1,082 & 75,000 & $3,095,051$ & 655,498 & $2,439,553$ & 21 \\
& & & & & & & \\
2014 & $2,767,053$ & 1,351 & 445,704 & $3,429,889$ & $1,767,649$ & $1,662,240$ & 52 \\
& & & & & & & \\
2015 & $3,657,055$ & 10,706 & 306,214 & $3,657,055$ & $1,315,517$ & $2,341,538$ & 36 \\
& & & & & & & 19 \\
\hline
\end{tabular}

Table 4.3. Port Charges Comparison of Ports

\begin{tabular}{|lcccccc|}
\hline Cargo & \multicolumn{7}{l}{ Port charges (USD) full container } & & & \\
& Aden & Hodeida & Port Sudan & Berbera & Mombassa & Djibouti \\
20 & 228 & 235 & 127 & 200 & 157 & 405 \\
$40^{\prime}$ & 301 & 159 & 172 & 300 & 195 & 810 \\
\hline
\end{tabular}

